\title{
Southeast Asian market entry mode choice of Chinese firms under the Belt and Road Initiative
}

\author{
Yu Fan \\ Business School \\ Yunnan University of Finance and Economics \\ Kunming, China \\ bpippen@163.com \\ Zhao Ying \\ Zhonghua Vocational College
}

\author{
Yunnan University of Finance and Economics \\ Kunming, China \\ yinduoes@qq.com \\ Yao Jianfeng* \\ Yunnan Business Research Institute \\ Yunnan University of Finance and Economics \\ Kunming, China \\ yjf4311@hotmail.com
}

\begin{abstract}
Based on extant foreign market entry mode choice literature and status analysis under the Belt and Road Initiative, this study has investigated four groups of factors that influence Chinese firms' entry mode choice for the Southeast Asian market, and has proposed a model with three groups of comprehensive indicators to evaluate an entry mode, in order to provide guidance for decision makers.
\end{abstract}

Keywords-entry mode; southeast Asian market; the Belt and Road Initiative

\section{INTRODUCTION}

International entry modes represent one of the most researched fields in international management. An entry mode can be defined as a structural agreement that allows a firm to implement its product market strategy in a host country [1]. Multinational firms may enter foreign markets by making a direct investment, in partnership with local companies, or through direct exports. Figure 1 presents a hierarchical model of market entry modes, which has three levels.



Fig. 1. A Hierarchical Model of Choice of Entry Modes [2]

\section{A. Classical Theories}

The most commonly used theories in entry mode research are the following ones which formed before 1990s [3].

\section{1) Transaction Cost Theory}

* Corresponding author
Transaction costs are costs incurred in making an economic exchange of some sort, which can be divided into three categories: search and information costs, bargaining costs and policing and enforcement costs [4]. The basic rationale behind transaction cost theory is that firms need to create governance structures that can minimize costs and

inefficiencies associated with entering and operating in a foreign market [5].

\section{2) Monopolistic Advantage Theory}

According to monopolistic advantage theory, a foreign investor is a monopolist or an oligopolist in product markets. The investor possesses some kind of advantage not available to local firms, such as economies of scale, superior technology, or superior knowledge in marketing, management, or finance [6]. Therefore, enterprises should focus on their own monopolistic advantages when entering the foreign market.

\section{3) Internalization Theory}

Internalization theory explains the practice of multinational enterprises to execute transactions within their organization rather than relying on an outside market, which consists of four stages [7]: (1) firms do not have regular exports, (2) firms export through agents, (3) firms sell through subsidiaries, and (4) firms begin overseas production. Enterprises should select the entry mode that can match their internal tendency.

4) $O L I$

OLI, also referred to as the eclectic framework, is based on the notion that the choice of an entry mode for a target market is influenced by three types of determinant factors: ownership advantages, location advantages and internalization advantages [8]. More specifically, ownership advantages relate to control, costs, and benefits of inter-firm relationships; location advantages concern resource availability and resource commitment; and internalization advantages refer to the concern for reducing coordination and transaction costs.

5) Resource-based view

With the assumptions that strategic resources are heterogeneous and immobile, this theory refers to the idea that in order to generate sustained competitive advantages, firm 
resources must be valuable, rare, inimitable and nonsubstitutable [9]. Multinational enterprises should choose the most effective entry mode to transfer and utilize their strategic resources and capabilities.

\section{B. Recent Research}

Most of researches on foreign market entry mode recently are the development and demonstration of these classical theories. Transaction cost theory is the most frequently used theoretical perspective, followed by OLI and resource-based view [10]. Studies applying transaction cost theory have shown the importance of environmental uncertainty and asset specificity, and have found that: when the environmental uncertainty is high, firms are more likely to adopt non-equity entry modes [11]; firms with high asset specificity tend to prefer entry mode with high control [12]; firms will choose high-control entry mode when both of them are high [13]. Studies using OLI discussed ownership advantages and location advantages a lot, and have found firms with both advantages tend to choose equity entry modes [14]. Studies using resource-based view have found that: firms tend to choose wholly-owned entry mode in order to protect their advantages [15]; this relationship is stronger when the host country's environmental uncertainty is higher [16].

Spurred by technological advances in communications and transportation, Chinese firms are now finding it easier to expand internationally. However, Chinese firms interested in servicing the foreign market face a problem with regards to entry mode selection, which is a frontier issue for Chinese scholars. Researches in China have contributed a lot to the theoretical construction of entry mode selection in these years. Earlier researches introduced and promoted the classical theories with China's reality. Then the studies can be divided into two categories: one category focused on the determinant factors of entry mode choice, such as market circumstances [17], industrial structure [18], institutional distance [19] and so on; the other tried to find out the relationship between entry mode selection and firm performance [20][21], but the conclusions are quite different.

In view of the existing researches, domestic and foreign scholars have studied the entry mode problem with different levels and different perspectives, involving investment motivation, strategy selection, firm performance and so on. But these studies still have some shortcomings: so many factors have been found affecting the entry mode selection, but they are not helpful enough for firms' decision-making; most scholars defined firm performance as financial performance, while entry mode selection may have comprehensive influences to a multinational enterprise.

One study should not expect to find a suitable decision mode for all enterprises to enter any foreign market. This study concerns about companies in China which are interested in servicing the Southeast Asian market, so as to lessen the two deficiencies of entry mode researches partly.

\section{BACKGROUND OF CHINESE ENTERPRISES TO ENTER SOUTHEAST ASIAN MARKET}

Economic globalization is the mainstream of world economic development, an important symbol of which is the rapid development of cross-border business. The Belt and Road (B\&R) Initiative was unveiled in 2013 in announcements revealing the "Silk Road Economic Belt" and "Maritime Silk Road", focusing on connectivity and cooperation among countries primarily between China and the rest of Eurasia. China's export links to the B\&R area have entered a new stage of development under the initiative. The national trade network density in this area increased year by year, and China has become the core of the network since 2013. In the case of little change in comparative advantage structure, new measures were introduced for opening China up, rapid progress was made in pursuing B\&R Initiative, and a number of major projects and industrial-capacity cooperation projects with other countries were launched.

There are six major areas along B\&R, where Chinese enterprises made direct investment in 50 countries in 2015. From the perspective of investment flows, the top 10 countries are presented in table I, and six of the countries are in Southeast Asia.

TABLE I. CHINA's FDI TO COUNTRIES IN B\&R AREA, 2015

\begin{tabular}{|c|c|}
\hline \multicolumn{2}{c}{ (Billions of Dollars) } \\
\hline Country & Flows \\
\hline Singapore & 10.45 \\
\hline Russia & 2.96 \\
\hline Indonesia & 1.45 \\
\hline The United Arab Emirates & 1.27 \\
\hline India & 0.71 \\
\hline Turkey & 0.63 \\
\hline Vietnam & 0.56 \\
\hline Laos & 0.52 \\
\hline Malaysia & 0.49 \\
\hline Kampuchea & 0.42 \\
\hline
\end{tabular}

a. From "2015 Statistical Bulletin of China's Outward Foreign Direct Investment” by Ministry of Commerce of the PRC

China and Southeast Asian countries have mutually beneficial relations of cooperation, and the trade history between China and some of the countries has been more than 2,000 years. In South Asia, the prices of labor production are generally low, and the infrastructure is relatively weak, so Chinese firms can focus on the development of manufacturing, labor-intensive industries and infrastructure investment [22]. Chinese government has built a three-dimensional channel connecting Southeast Asia with roads, railways, water transport, and aviation.

Chinese enterprises now have an unprecedented opportunity to enter Southeast Asian market with favorable climate and geographical position and support of the people. However, Chinese multinational enterprises are not so experienced, with a great distance from the renowned multinational enterprises. Entry mode choice has become an important and unavoidable problem for them. In next part, we present a model of entry mode choice that extends extant theories, trying to help Chinese enterprises make the Southeast Asian market entry mode decision.

\section{FACTORS THAT INFLUENCE SOUTHEAST ASIAN MARKET ENTRY MODE SELECTION}

Factors that influence entry mode selection are often classified into home country-specific variables, host countryspecific variables, company-specific variables, and venture- 
specific variables [23]. In this research, we also choose four groups of variables that are shown to exert a strong influence on the Southeast Asian market entry mode decisions.

\section{A. Host Country Factors}

There are at least three key dimensions of the host country environment associated with the entry mode choice: (1) market circumstances, which refers to host country's market size and competition; (2) investment risk, which refers to host country's policies and regulations; (3) cultural distance, which refers to differences in ideology, language and social structure between the home country and the host country. The relevant host country factors are all presented in table II.

TABLE II.

HOST COUNTRY FACTORS

\begin{tabular}{|c|c|}
\hline Main factors & Sub factors \\
\hline \multirow{4}{*}{$\begin{array}{c}\text { Market } \\
\text { circumstances }\end{array}$} & Number of local competitors \\
\cline { 2 - 2 } & Intensity of related industries \\
\cline { 2 - 2 } & Local demand stability \\
\cline { 2 - 2 } & Local market potential \\
\hline \multirow{4}{*}{$\begin{array}{c}\text { Investment } \\
\text { risk }\end{array}$} & Free competition in local market \\
\cline { 2 - 2 } & Political and economic instability \\
\cline { 2 - 2 } & Foreign exchange control \\
\cline { 2 - 2 } & Prictions on foreign ownership \\
\cline { 2 - 2 } & Risk of forfeiture of assets equipment \\
\hline \multirow{3}{*}{$\begin{array}{c}\text { Cultural } \\
\text { distance }\end{array}$} & Customs gap \\
\cline { 2 - 2 } & Language gap \\
\cline { 2 - 2 } & Corporate culture distance \\
\cline { 2 - 2 } & Differences of enterprise management system \\
\hline
\end{tabular}

\section{B. Home Country Factors}

Three main factors of the home country are related to the entry mode choice: (1) environmental munificence, which refers to the natural resources and the ability to support growth; (2) environmental volatility, which refers to the level of instability facing a domestic environment; (3) environmental complexity, which refers to the concentration of the home market. Details are presented in table III.

TABLE III.

HOME COUNTRY FACTORS

\begin{tabular}{|c|c|}
\hline Main factors & Sub factors \\
\hline Environmental & Abundance of natural resources \\
\cline { 2 - 2 } munificence & The ability to sustain economic growth \\
\hline Environmental & Political and economic instability \\
\cline { 2 - 2 } volatility & Domestic demand \\
\hline \multirow{2}{*}{$\begin{array}{c}\text { Environmental } \\
\text { complexity }\end{array}$} & Market competition \\
\cline { 2 - 2 } & Scarcity of resources in the market \\
\cline { 2 - 2 } & Market saturation \\
\hline
\end{tabular}

\section{Organizational Factors}

The capabilities of a firm are strongly rooted in the home country, so transferring them to a dissimilar host country is difficult and it is linked to high learning costs. There are five dimensions of the organizational capabilities associated with the entry mode choice: basic capabilities, dynamic capabilities, firm size, international experience and technical concealment, as shown in table IV.

TABLE IV.

ORGANIZATIONAL FACTORS

\begin{tabular}{|c|c|}
\hline Main factors & Sub factors \\
\hline \multirow{4}{*}{$\begin{array}{c}\text { Basic } \\
\text { capabilities }\end{array}$} & Ability to develop new products \\
\hline & Technological innovation \\
\hline & Ability to cope with market demand \\
\hline & Ability to manage and coordinate with other vendors \\
\hline \multirow{3}{*}{$\begin{array}{l}\text { Dynamic } \\
\text { capabilities }\end{array}$} & Ability to dynamically allocate resources \\
\hline & Learning ability \\
\hline & Reconfiguration and transformation of knowledge \\
\hline \multirow{2}{*}{ Firm size } & Enterprise capital \\
\hline & Number of employees \\
\hline \multirow{2}{*}{$\begin{array}{c}\text { International } \\
\text { experience }\end{array}$} & International operation time \\
\hline & International operation area \\
\hline \multirow{3}{*}{$\begin{array}{c}\text { Technical } \\
\text { concealment }\end{array}$} & Non transfer-ability \\
\hline & Complexity \\
\hline & Scarcity \\
\hline
\end{tabular}

\section{Strategy Factors}

There are three main factors about the enterprises' strategies that may have influences on the entry mode choice: (1) industrial structure, which refers to the intensity of competition in a market; (2) strategy motivation, which refers to the required level of control to achieve a firm's objectives in the host market; (3) global synergy, which refers to foreign affiliates around the world sharing valuable information, knowledge, technology and experience with the parent firm. Details are presented in table V.

TABLE $V$.

\begin{tabular}{|c|c|}
\hline Main factors & Sub factors \\
\hline \multirow{3}{*}{$\begin{array}{c}\text { Industrial } \\
\text { structure }\end{array}$} & Product differentiation \\
\cline { 2 - 2 } & Possibility of price war \\
\cline { 2 - 2 } & Concentration of related enterprises \\
\hline \multirow{4}{*}{$\begin{array}{c}\text { Strategy } \\
\text { motivation }\end{array}$} & Expanding market share \\
\cline { 2 - 2 } & Constructing international marketing channels \\
\cline { 2 - 2 } & Access to scarce resources \\
\cline { 2 - 2 } & Acquiring advanced technology \\
\hline \multirow{3}{*}{ Global synergy } & Risk reduction \\
\cline { 2 - 2 } & Technology sharing \\
\cline { 2 - 2 } & R \& D resource sharing \\
\hline
\end{tabular}

\section{EVALUATION OF FOREIGN MARKET ENTRY MODE}

A firm's entry mode choice will influence post-entry decisions and performance. Multinational enterprises need to evaluate a foreign market entry mode in order to make better decisions in the future. In this part, we proposed a comprehensive model with three categories of indicators: financial indicators, anti risk indicators, growth indicators. We constructed pairwise comparison matrix among all the sub indicators by asking the experts which one is more important, and then calculated the relative weights (reference value).

Decision makers are expected to be aware of the main costs and benefits associated with different entry modes, and their final decision should be checked with facts. In the performance appraisal of the chosen entry mode, experts and managers can give it a score using table VI-VIII. If the score is below average, an entry mode change deserves serious consideration in the internationalization process of this firm. 
TABLE VI.

FINANCIAL INDICATORS

\begin{tabular}{|c|c|c|}
\hline Main indicators & Sub indicators & Weights \\
\hline \multirow{3}{*}{$\begin{array}{c}\text { Capital } \\
\text { profitability }\end{array}$} & Return on assets & 0.07 \\
\cline { 2 - 3 } & Return on capital & 0.43 \\
\hline \multirow{2}{*}{$\begin{array}{c}\text { Sales revenue } \\
\text { ability }\end{array}$} & Return on equity & 0.20 \\
\cline { 2 - 3 } & Return on net sale & 0.02 \\
\cline { 2 - 3 } & Net profit margin on sales & 0.11 \\
\hline \multirow{2}{*}{$\begin{array}{c}\text { Debt paying } \\
\text { ability }\end{array}$} & Cost-profit ratio & 0.07 \\
\cline { 2 - 3 } & Asset liability ratio & 0.01 \\
\cline { 2 - 3 } & Capital turnover & 0.06 \\
\hline \multirow{2}{*}{} & Quick ratio & 0.03 \\
\hline
\end{tabular}

TABLE VII.

ANTI RISK INDICATORS

\begin{tabular}{|c|c|c|}
\hline Main indicators & Sub indicators & Weights \\
\hline \multirow{3}{*}{ Macro risk } & Business risk & 0.04 \\
\cline { 2 - 3 } & Policies risk & 0.39 \\
\cline { 2 - 3 } & Social risk & 0.18 \\
\hline \multirow{3}{*}{ Regional risk } & Potential competition risk & 0.07 \\
\cline { 2 - 3 } & Market demand risk & 0.18 \\
\cline { 2 - 3 } Specific risk & Market potential risk & 0.04 \\
\cline { 2 - 3 } & Product marketing risk & 0.07 \\
\cline { 2 - 3 } & Product cost risk & 0.02 \\
\cline { 2 - 3 } & Product location risk & 0.01 \\
\hline
\end{tabular}

TABLE VIII.

GROWTH INDICATORS

\begin{tabular}{|c|c|c|}
\hline Main indicators & Sub indicators & Weights \\
\hline \multirow{2}{*}{$\begin{array}{c}\text { Ability to meet } \\
\text { customers' needs }\end{array}$} & Customer satisfaction & 0.38 \\
\cline { 2 - 3 } & Providing satisfactory products & 0.18 \\
\cline { 2 - 3 } $\begin{array}{c}\text { Internal } \\
\text { capability }\end{array}$ & $\begin{array}{c}\text { Supply capacity } \\
\text { Operating and after-sales service } \\
\text { capabilities }\end{array}$ & 0.06 \\
\cline { 2 - 3 } & Employee productivity & 0.01 \\
\cline { 2 - 3 } Learning ability & Innovation ability & 0.04 \\
\cline { 2 - 3 } & Employee collaboration & 0.08 \\
\cline { 2 - 3 } & $\begin{array}{c}\text { Internal information } \\
\text { communication }\end{array}$ & 0.03 \\
\cline { 2 - 3 } & Employee morale & 0.13 \\
\hline
\end{tabular}

\section{CONCLUSION}

Foreign market entry mode research is important because the chosen entry mode determines whether a company has full control over the foreign unit or has to share control with partners, which has significant implications for performance. Given certain characteristics of the environment, the firm, and the products, decision makers should choose an entry mode with best performance, which is really difficult.

Under the Belt and Road Initiative, Chinese firms now have an unprecedented opportunity to enter Southeast Asian market with great support. This study has investigated factors (4 groups, 14 main factors, $46 \mathrm{sub}$ factors) that influence Chinese firms' entry mode choice for the Southeast Asian market. When these factors are jointly examined, an efficient entry mode selection can be made. In order to summarize the experience of transnational operations, the chosen entry mode need to be evaluated. This study has proposed a model with comprehensive indicators (3 groups, 9 main indicators, $27 \mathrm{sub}$ indicators), through which the managers can score for each entry mode and then decide whether to make a change or not. In the future research, we may try to verify the proposed model through empirical studies.

\section{ACKNOWLEDGMENT}

We would like to thank Professor Wang and Professor Liu, for their valuable comments that help us improve this paper.

\section{REFERENCES}

[1] V.M. Sharma, and M.K. Erramilli, "Resource-Based Explanation of Entry Mode Choice," Journal of Marketing Theory \& Practice, vol. 12, 2004, pp. 1-18.

[2] Y. Pan, and D.K. Tse, "The Hierarchical Model of Market Entry Modes," Journal of International Business Studies, vol. 31, 2000, pp. 535-554.

[3] A. Canabal, and G.O. White, "Entry mode research: Past and future," International Business Review, vol. 17, 2008, pp. 267-284.

[4] C.J. Dahlman, "The Problem of Externality," The Journal of Law and Economics, vol. 22, 1979, pp. 141-162.

[5] J.F. Hennart, "Can the 'New Forms of Investment Sustitute' for the 'Old Forms'? A transaction Costs Perspective," Journal of International Business Studies, vol. 20, 1989, pp. 211-234.

[6] V. Kumar, and V. Subramanian, "A contingency framework for the mode of entry decision," Journal of World Business, vol. 32, 1997, pp. 53-72.

[7] J. Johanson, and J.E. Vahlne, "The Internationalization Process of the Firm-A Model of Knowledge Development and Increasing Foreign Market Commitments," Journal of International Business Studies, vol. 8, 1977, pp. 23-32.

[8] J.H. Dunning, "Toward an eclectic theory of international production," Journal of International Business Studies, vol. 11, 1980, pp. 9-31.

[9] J.B. Barney, "Firm Resource and Sustained Competitive Advantage," Journal of Management, vol. 17, 1991, pp. 99-120.

[10] J. Bruneel, R. De cock, "Entry Mode Research and SMEs: A Review and Future Research Agenda," Journal of Small Business Management, vol. 54, 2016, pp. 135-167.

[11] F. Bradley, and M. Gannon, "Does the Firm' s Technology and Marketing Profile Affect Foreign Market Entry?" Journal of International Marketing, vol. 8, 2000, pp. 12-36.

[12] R.B. Mcnaughton, "Foreign market channel integration decisions of Canadian computer software firms," International Business Review, vol. 5, 1996, pp. 23-52.

[13] B. Maekelburger, C. Schwens, and R. Kabst, "Asset specificity and foreign market entry mode choice of small and medium-sized enterprises: The moderating influence of knowledge safeguards and institutional safeguards," Journal of International Business Studies, vol. 43, 2012, pp. 458-476.

[14] J.C. Pinho, "The impact of ownership: Location-specific advantages and managerial characteristics on SME foreign entry mode choices," International Marketing Review, vol. volume 24, 2007, pp. 715-734.

[15] S.H. Akhter, F. Robles, "Leveraging Internal Competency and Managing Environmental Uncertainty: Propensity to Collaborate in International Markets," International Marketing Review, vol. 23, 2006, pp. $98-115$.

[16] C. Schwens, J. Eiche, and R. Kabst, "The Moderating Impact of Informal Institutional Distance and Formal Institutional Risk on SME Entry Mode Choice," Journal of Management Studies, vol. 48, 2011, pp. 330-351.

[17] H.M. Zhang, D.Q. Zhou, and D.Y. Shen, "Entry Mode Selection Based on Market Competition Analysis," Energy Technology and Management, vol. 5, 2007, pp. 86-89.

[18] L.Q. Chen, "The Conception of Building Yunnan Province into the Electric Power Cooperation Corridor between the Pan-pearl River Delta and the ASEAN," Journal of Yunnan University of Finance and Economics, vol. 24, 2008, pp. 93-100.

[19] K.H. Li, R.H. Lin, and Y. Li, "The Effect of Regulative Institutional Distance on Chinese Overseas Subsidiaries' Choice of International Entry Modes," Forum on Science and Technology in China, vol. 9, 2016, pp. 78-84.

[20] Y.C. Chang, "Dynamic Characteristics of Overseas Direct Investment Performance of Chinese Enterprises: An Empirical Analysis Based on 
Large State-owned Enterprises,” Finance \& Trade Economics, vol. 2, 2011, pp. 87-94.

[21] Z.M. Yin, Z.B. Yuan, and Z. Fu, "The Influence of Cultural Distance on Transnational Corporations' Performance," Contemporary Economic Research, vol. 2, 2013, pp. 37-41.

[22] R. Liu, and F. Gao, "The Belt and Road Strategy Resolving the Traditional Industry Overcapacity," Social Science Research, vol. 1, 2016, pp. 45-56.

[23] C.W. Hill, P. Hwang, and W.C. Kim, "An eclectic theory of the choice of international entry mode," Strategic Management Journal, vol. 11, 1990, pp. 117-128. 